\title{
Government Information Access: A decisive Factor for E-Government
}

\author{
Yikun Xia 1 Cui Huang2 \\ 1 Yikun Xia, Center for Studies of Information Resources, \\ Wuhan University, Wuhan, P.R.China, 430072 \\ xykwhu@126.com \\ 2 Cui Huang, School of Public Management, Zhejiang University, \\ Hangzhou, P.R.China, 430072 \\ huangcui@x263.net
}

\begin{abstract}
In recent years we are witnessing enormous development of e-government, which has brought about great changes in our society. This study examines the relationship between the levels of egovernment and the quality of government information access, pointing out that e-government principles are based on the assumption that government information should be accessed among all kinds of organizations. In contrast to government webs' rapid growth, the low quality of government information access has been a dilemma which impacts the usability and efficiency of e-government. This paper also analyzes blocking factors about information access in China, draw a conclusion that on-line government information access should be the key factor of e-government which steps should be taken to enhance accessibility to government information.
\end{abstract}

\section{Introduction}

Through over ten year's development, E-Government becomes a fundamental part of government's public service reform agenda. In China, by the end of Jun 2006, the population of government websites using the DNS of ".gov.cn" has reached almost 12 thousand. At present, $96 \%$ of departments of state council in our country have established government websites and nearly $90 \%$ of governments at provincial level, $96 \%$ of governments at municipal level and $77 \%$ governments at country level have their own government websites. [1] With more and more funds, technology and devices added, the hardware environment of E-Government gets better and better, while the conditions for information access is not simultaneously promoted, the gap

\footnotetext{
Please use the following format when citing this chapter:
}

Xia, Y., Huang, C., 2007, in IFIP International Federation for Information Processing, Volume 252, Integration and Innovation Orient to l-Society Volume 2, eds, Wang, W., (Boston: Springer), pp. 289-296. 
between information richer and poorer becomes more largely than ever, so the issue of government information access is put on the agenda.

As the necessity of the times, the appearance and the widespread application of e-government not only changes government information flow and work system, but also plays a decisive role in information access, improving government information sharing and thus building the social information justice. Therefore, the aims of this paper are to (i) provide a brief review about the great changes of government information access brought by e-government, (ii) to investigate the relationship between government information access and e-government, (iii) to determine obstacles of on-line government information access in China, (iv) to propose a model to develop e-government on the base of government information access.

\section{Government Information Access: Key Characteristic of E- Government}

\subsection{Changes of Information Access in E-Government Environment}

Although users, information providers, information channels and information environment are all important factors for information access and should be given equal attention, so far as government information access is concerned, owing to the actual unequal positions of information owners and information demanders, the power to control information access is always unilaterally held in government. How to accelerate government information flow and eliminate information monopoly becomes the main problem. Because "electronic information access strategies and programs are a consistent feature of e-government initiatives [2]", e-government provides a realistic way.

"Access" means different information to different users at different time, today, it is controlled by technologies available. Because "this kind of change demands a foundation of valid information exchange between government and the citizen." [3] The development of web technology not only laid substantial technological foundation for e-Government, but also created unprecedented conditions and advantages to improve and promote government information sharing.

$>$ The expansion of information access users

The development of e-government moves citizens out of line onto the internet successfully, making anyone any organization gain information from the open online information source with lower cost. In South Korea, citizens do not need to visit government offices because $75 \%$ of the required documents can be issued online[4]. In the United States, three-quarters of e-government users believe that e-government has made it easier and more convenient for them to stay informed about government services[5].

$>$ The improvement of information access effect

Information access effect differs in the level of detail, the quantity or type of data exchanged. It is dependent on a common way to integrate diverse information residing in different government departments. So e-government is looked as the second revolution in government information service domain after the information 
resources management idea, providing prompt one-stop service on line, integrating all kinds of information resource have already promoted public information demand, realizing the breakthrough and the innovation in the method and pattern of government information service.

The content deepening

The complicated combination of data and kinds of web language and technical factors further enriches the manifestation of government information online. On the one hand, the integrated use of text, image, video and audio improves the expressiveness and influence of government information communication on website, attracting more and more people to visit government website, on the other hand, an e-government framework requires transparency of information which stimulates information flow and transfers massive amounts of unused government information to useful information needed in social life.

$>$ The demonstration of information access benefits

The experience features of information products not only caused different users' effect, but also made it difficult to judge the benefits of e-government directly. The effect of government information access are not only reflected in the great changes brought about after government information was open and communicated, but also in the organic connection of government information process and government affairs process, make information access and information implementation intersect and furthermore promote government administrative reform process.

$>$ The changes in the structure of information access

E-Government broke the previous order of up-down government information access and replaced it with a process of interact information access. Bottom-up or lateral information flow not only constructs intersected network for government information access, but also enables the users to become important participants in the chain of government information producing, hence improve the relationship between users and government department, making e-government stage advanced to the more superior transaction model from the information model gradually

\subsection{Government Information Access: Demonstrating Benefits of E- Government}

In United States, "Citizens not only visit government Web sites, but also use the information they find. Close to two-thirds of government Web site users say they have sought information on public policy issues via government sites, while Seventy-two percent said their use of government Web sites has improved the way they interact with state government at least a little[6]. "In Britain, the vast majority of government services can be obtained from the government websites. The practice of e-government's in Western countries demonstrates that obtaining necessary documents and information from government websites has gradually played an increasingly important role in the public domain.

In attention extremely limited time, stressing information access truly reflects the core value of e-government:

First, information access has become an important factor of e-government practical effect evaluating, because in essence, the difference of a 'good' government 
and a 'bad' government is reflected in how to predominate and handle information. And, the distinguish between e-government and e-commerce mainly lies in the social information justice maintenance, emphasize the equal opportunity of information access. The past e-government models whether based on technology-centered or government-centered were only adapted to convenient government itself, which is difficult to be utilized by citizen. However, the outstanding nature of e-government model should provide an open channel for the users to access public information.

Second, government information access is an inevitable choice for the transformation of government information workflow, the innovation of government management and the accomplishment of e-government goal. Information is the key factor to successful innovation, in terms of content, government information is egovernment's "blood", to some extent, the successful e-Government is critically dependent on the access effect of its integral information.

Third, the stress of information access is also the maintenance of user's right of information freedom. The current way of government's web site design and information integration is ruled by customer-centric principle. The e-government assessment reports made by Accenture Company have well reflected this trend that e-government should pay more attention on customer feelings, for example, in 2003,the subject was "e-Government Leadership: Engaging the Custom", in 2005, "Leadership in Customer Service: New Expectations, New Experiences" , in 2006, "Leadership in Customer Service : Building the Trust"(2006).

"In the future society, the on-line information will become the distinct characteristic of democratic system" [7], Through the improvements of information access, government will provides a new framework of thinking and acting for information management, coordinate the interests of all parties and maximize the effectiveness and value of government information. Meanwhile, as a "checks and balances", public access is an independent way for citizens to know what their government is doing (fig Description of the relationship between information access and e-government).

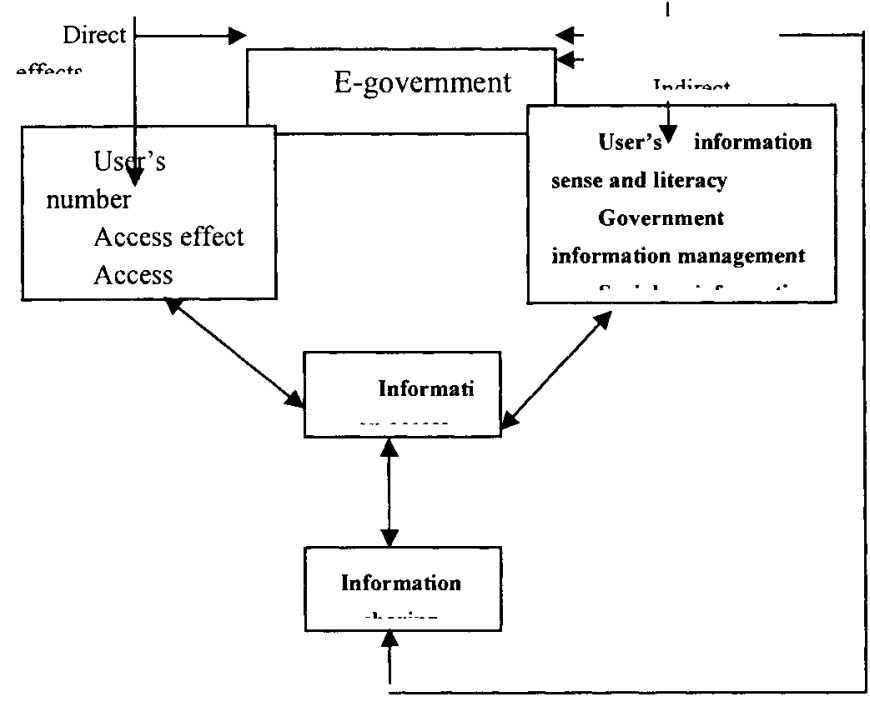

Fig.1. Description of the relationship between information access and e-government 


\section{The Low Effect of Government Information Access: the Main Restricting Factor on the Success of E-Government}

\subsection{Connotation of Government Information Access Online}

Being the "Out put" of e-government, government website can be a contact platform for $\mathrm{G} 2 \mathrm{C}$ (government to citizen). From the perspective of users, whether based on technology or content, government information access is a very broad concept. Putting aside the technical factors, such as the status of interfaces, system interoperability, web site security, only judged from the perspective of information content, the quality of government information access can be examined from characteristics among information scope, content and user's participation:

The scope refers to the width, depth, time span and the format diversity of information and so on.

The content includes authenticity and accuracy, timeliness, relevance, integrity and easier usability (conditions of information organizing, ease of access).

The user's participation focuses on both user's amount and constitution of occupation.

Information access in e-government is assumed to be able to collect,manage, evaluate information used and identify needs. It thus needs relative resource management of human being, computers, users, information training and digital data. Because "this demand for direct access to government information, from both inside and outside government, is influencing the design and management of these information services. [8]".

\subsection{The Negative Influence on E-Government Due to the Low Effect of Government Information Access}

"As states migrate most of their public information to the web, access is improved for many people. However, states need to take care that this on-line migration does not provide new obstacles to others. [9]" In fact, even in developed countries, ignorance of government information access has greatly impaired government website's usability, thus the popularization of e-government still faces challenge. A survey conducted by the United States showed that nearly half of the population had never used the Internet and $57 \%$ of them said that they were not interested in the Internet service[10]. In Britain, only $10 \%$ of the citizens had interactive activities with government through Internet[11].

Various surveys show that, although most government departments have built up their own websites, few people noticed whether the government website was designed to facilitate the public. On the one hand, the low effect of government information access has caused a large number of government websites stagnate at a lower stage of simply information release and in turn, the degree of government computerization determines whether the public use online e-government services. Therefore, it is often the case that citizens have difficulty in access public information, thus implying a lack of information transparency. only when 
government websites that are built on the basis of convenient to information access can really attract participation from the public and establish more democratic governments. The government website construction must be developed centering on information access so that e-government can become an advanced perception and ideal model.

\subsection{Analyzing Restriction Factors on Chinese Government Information Access}

In practice, the technical dependence of e-government provides the opportunity for technical bureaucrat to control government website operation and information publicity and utilization. the current e-government in our country is lack of effective information access. In 2006, the main web services used by Chinese Internet users is browsing news, search engines and delivery of Email, E-government ranks No. 24, taking up only $5.4 \%[12]$. According to factors analyzing on government information access, the main problems in our country are as follows:

$>\quad$ Low total supply quantity . On the one hand, because of the lack of government information openness, a lot of government information is limited in specific government system because of fear losing autonomy; on the other hand, the isolation between government website designers, information management staff and government affairs processing results in discrepancy between internet government information process and government affairs process. In 2005 , only $44.5 \%$ of all the government websites released over $60 \%$ of information, while $21.7 \%$ of the websites released less than $20 \%$ of information [13].

$>$ Broadly scope and depth insufficient. According to various Internet survey results, the main information content provided on Chinese government websites are in turn of government news, government function/business introduction, statistic data/materials search, laws and regulations/policy documents, etc. Although there are lots of categories of content, the depth of information processing can't satisfy users' need, and in particular, the structure of government information supply can't match that of users' information need also, the inefficiency in government information access caused by the differences between demand and supply will then affect social popularization of e-government.

$>$ Single manifestation and insufficient interactive usability. Government information on-line is mainly displayed in static forms, with few dynamic forms like image, video and many text databases, and the lack of multimedia information and full text databases severely impairs the vivacity and attraction of government website. Besides, government information updates slow, the most quickly updating information type is government news, while the most slow update type is necessary information needed in social life like business guide.

$>$ Imbalance distribution of information. There is an obvious tendency in government information distribution from different government websites, eastern provinces full of information whereas western provinces lack of it. At the same time, the content and quality provided on government website might be different because of different attributes and levels of government institutions. The amount of government information owned and provided by central government and municipal government websites is not at same level. 
$>$ A bureaucratic access way. On the one hand, many government websites were designed without taking accessibility account and caused disorder in government information classifying. According to statistics, the percentages of websites whose services are categorized by users in municipal and country-level governments are only $8.7 \%$ and $3.2 \%$ respectively, while the percentages of those categorized basically by government departments are as high as $48.1 \%$ and $50.4 \%$ respectively[14]; on the other hand, since they are designed primarily for simple information releasing, they also lack efficient support for representing the exchange of complex information and forming interaction between officials and users.

$>$ High access cost. cost is an important factor in determining users' information access methods. No matter examined from the popularization of information infrastructure, or users' surfer fee, or time cost, government information access in our country is not inexpensive. And the high cost in turn result in the drop of government information using and inefficiency of e-government.

\section{Conclusion}

"Information age can be taken as an opportunity of liberation, but only when information providers keep supporting the objective of equally accessing information, technology can open various information sources" [15]. In a certain sense, the success of E-Government depends on the degree of government information access realization. So, it is necessary for us to take steps as follows:

$>$ Recognize the importance of information access, taking the availability of information as the starting point during website planning, design and management.

$>$ Design and construct E-Government project aimed at the principle of convenient user's information access, clearing up all kinds of barriers to broad government information access and building an effective E-Government pattern finally.

Provide multiple information access channels, to expand the information service target and scope, and to push and integrate all the users into the digital ages as far as possible.

$>$ Provide relevant training in order to expand public ability of information access.

\section{Acknowledgments}

This research is supported by National Planning Office of Philosophy and Social Science, P.R. China(07BTQ017).

\section{References}

1. The 18th report of Chinese internet development status statistics. http://www.cnnic.cn/ uploadfiles/doc/2006/7/19/103601.doc 
2. Sharon S. Dawes, Theresa A. Pardo, and Anthony M. Cresswell, Designing electronic government information access programs: a holistic approach, Government Information Quarterly, 21 (2004), pp.3-23.

3. Hart-Teeter. The New E-Government Equation: Ease, Engagement, Privacy \& Protection.

http://coexgov.securesites.net/admin/FormManager/filesuploading/egovpoll2003.pdf (current 10 July.2007)

4. Young-Jin, Shin. Establishing e-Government through Government Information Sharing. http://egov.epfl.ch/UserFiles/File/Shin_Presentation.pdf. (current 10 July.2007)

5. Hart-Teeter. The New E-Government Equation: Ease, Engagement, Privacy \& Protection. http://www.excelgov.org. (current 10 July.2007)

6. Jody Condit Fagan and Bryan Fagan. An accessibility study of state legislative Web sites. Government Information Quarterly, 21 (2004), pp.65-85.

7. Douglas Holmes. eGov: eBusiness Strategies for Government. Nicholas Brealey Publishing, (2003), pp.212

8. Sharon S. Dawes, Theresa A. Pardo, and Anthony M. Cresswell. Designing electronic government information access programs: a holistic approach. Government Information Quarterl , 21 (2004) , pp.3-23

9. Jody Condit Fagan and Bryan Fagan. An accessibility study of state legislative Web sites. Government Information Quarterly, 21 (2004), pp.65-85.

10. Lenhart, A., Rainie, L, Fox, S., Horrigan, J., and Spooner, T. Who's not online: $57 \%$ of those without Internet access say they do not plan to log on. Pew Internet \& American Life Project. http://www.pewinternet.org/. (current 10 July.2007)

11. Booz, Allen, Hamilton. International e-economy benchmarking: the world's most effective policies for the e-economy. http://www.itis.gov.se/publikationer/eng/ukreport.pdf(current 10 July.2007)

12. The 19th report of Chinese internet development status statistics. http://www.cnnic.cn/uploadfiles/pdf/2007/1/23/113114.pdf

13. The report of Chinese internet information resource 2005 http://www.cnnic.net.cn/download/2005/20050301.pdf (current 7 July.2007)

14. CCID Consulting Stock Ltd. The report of performance assessing on Chinese government websites2004. http:/www.ah.gov.cn/otherimages/baogao.pdf(current 7 July.2007)

15.Jody Condit Fagan and Bryan Fagan. An accessibility study of state legislative Web sites. Government Information Quarterly 21 (2004) 65-85 